\title{
A Model of Product Life Cycle Cost Management Based on the Example of the Spartan Multimedia Shooting Training System
}

\author{
Waldemar Swiderski ${ }^{1, *(D)}$ and Wieslawa Rolek ${ }^{2}$ \\ 1 Department of Simulators, Military Institute of Armament Technology, 05-220 Zielonka, Poland \\ 2 Department of Finance, Military Institute of Armament Technology, 05-220 Zielonka, Poland; \\ rolekw@witu.mil.pl \\ * Correspondence: waldemar.swiderski@wp.pl
}

Citation: Swiderski, Waldemar, and Wieslawa Rolek. 2021. A Model of Product Life Cycle Cost Management Based on the Example of the Spartan Multimedia Shooting Training System. Economies 9: 90. https:// doi.org/10.3390/economies9020090

Academic Editor: Roberta Salomone

Received: 3 March 2021

Accepted: 9 June 2021

Published: 11 June 2021

Publisher's Note: MDPI stays neutral with regard to jurisdictional claims in published maps and institutional affiliations.

Copyright: (c) 2021 by the authors. Licensee MDPI, Basel, Switzerland. This article is an open access article distributed under the terms and conditions of the Creative Commons Attribution (CC BY) license (https:// creativecommons.org/licenses/by/ $4.0 /)$.

\begin{abstract}
Cost management is a process that contributes to increases in efficiency that have an impact on a finished product. Comprehensive cost management uses information that is created by the cost accounting system and new concepts of measurement and valuation of product manufacturing costs. This paper presents the product life cycle costing (LCC) method and the target cost method as concepts used in cost management based on the example of the SPARTAN system. SPARTAN is a stationary training system designed to train, monitor and evaluate sighting and shooting techniques for small arms. The LCC method refers to the estimated cost of a product (in our case, the SPARTAN system) life cycle and it is calculated as the sum of the acquisition costs, ownership costs and operating costs. Having taken into account costs of acquisition, ownership and operation, the results of the LCC analysis were obtained, which show that, keeping in mind the whole life cycle cost, it will be more profitable to purchase the modernized version of the SPARTAN system despite its higher acquisition costs.
\end{abstract}

Keywords: life cycle costing; cost management; target costing; shooting training system

\section{Introduction}

The first decade of the 21st century has brought significant changes both in our environment and in the environment of enterprises. The causative factors of the transformations that have taken place are, among others, globalization processes, development of modern technologies, increased awareness and customer requirements and, above all, the dizzying development of computer science and electronics, which contributed to an increase in the efficiency of computers and systems for generating images. This has enabled building virtual environments initially used in entertainment in various types of computer games, and then creation of simulation techniques that can be used in practice.

Advances in computer science have also contributed to an evolution in the military domain. Every soldier and member of the armed forces is a user of small arms. For soldiers, the first contact with the assigned weapon is one of the most important moments during his/her service in uniform. Everyone knows the negative saying "to be like a soldier without a gun". Familiarization with the weapons that covers knowledge of small arms, their operation and principles of effective use is therefore an elementary part of training. Current requirements in this regard are increasing in a stepwise manner. This results from switching from conscript-based forces to those consisting of professional troops only and the related expectations of enhanced soldier proficiency, also in shooting. In addition, the importance of effective shooting skills development has grown in the age of global media. Soldiers and participants in peacekeeping and stabilization missions are required to use their weapons in a prudent and effective way. Any use of rifles or pistols against civilians may have tragic consequences, hence the millions of rounds of ammunition fired at shooting ranges and growing costs of preparing highly skilled and versatile soldiers. Therefore, in the training of troops, courses and drills play an important role that can be 
carried out virtually by means of simulators/trainers. The first SPARTAN small arms shooting trainers (in Poland this system is known under the name of SNIEZNIK) for military units of the Polish Armed Forces were delivered and fielded more than 15 years ago. Since then, the supply of trainers and current simulators has been continued, although the system itself underwent a significant upgrade at that time. Using the example of the abovementioned system, this paper discusses the process of economic analysis aimed at assessing the total cost of the system's acquisition, ownership and modernization. The methodology of the LCC (life cycle costing) analysis and the method of target costing were used for this assessment.

\section{SPARTAN Multimedia Shooting Training System}

SPARTAN is a stationary training system designed to train, monitor and evaluate sighting and shooting techniques for small arms and to prepare soldiers for (Swiderski et al. 2018; Glogowski et al. 2017):

- Live ammunition firing at open ranges at combat targets and silhouettes;

- Detection, classification and engagement of real targets in different kinds of terrain, weather conditions and time of the day;

- Teamwork, operating as a squad during missions by using different types of weapons;

- Suitable reactions in atypical scenarios.

Thanks to the modular structure of the trainer system, it can be configured according to individual training needs of the user. Current versions of the system are designed to carry out, among others, the following:

- Target spotting;

- Preparatory training for shooting;

- Shooting training;

- Combat shooting;

- Situational shooting;

- Training in fire control;

- Enhancement of knowledge of shooting rules and designs of weapon systems.

\section{Target Costing Method and Life Cycle Cost Method in Cost Management}

In the modern world, where globalization has achieved a very high level and competition is constantly growing, it is very important to use all the resources of economic analysis. A decision to purchase a new asset routinely is focused mainly on the cost of the initial purchase, no matter whether this refers to a single product or a system. Therefore, use of cost management methods, either in the form of the product life cycle cost (LCC) principle or the cost effectiveness assessment method, provides a more comprehensive and transparent representation of the total costs associated with both purchasing and operating a product. In case of the LCC method (PN-EN 60300-3-3 n.d.; PN-EN 60300-3-3:2017-07 n.d.), all expenses incurred throughout the entire life cycle, starting from the investment, i.e., from the moment of purchase, through ownership and operation up to final decommissioning, are taken into account (Spickova and Myskova 2015; Liapis and Kantianis 2015).

In the case of the SPARTAN system, the latter factor, i.e., the decommissioning cost, was not included in the cost calculation method.

The LCC method was originally designed for the US Department of Defense procurement and is still used in the military sector, but not only there, because it is also a very useful method in the construction industry (Azmat and Konzett 2014).

Langdon (2006) presented a detailed review of the literature on LCC in his work. He highlighted the fact that models of a high level of technical complexity used in many publications feature a low level of practical usefulness.

\subsection{Methods in Cost Management}

Target cost accounting is a cost management system designed to achieve an intended profit over the entire product life cycle. Being a modern accounting tool, it requires an 
involvement of various functional areas of the enterprise already at the planning stage. Therefore, target cost accounting takes into account all costs associated with a product throughout its life cycle. These include research and development costs, production costs and product recall costs. Considering the product from the point of view of three variables (price, quality, functionality) focusing on the customer and the market, and adopting a long-term cost management perspective, are the advantages confirming that target costing, i.e., the method of target costs, is a strategic instrument. Taking the above statement into account, target costing can be represented by the following equation:

$$
\text { Target price }- \text { target profit }=\text { target costing }
$$

This method can be broken down into the following stages:

- Market research;

- Product cost calculation;

- Product design;

- Product manufacturing.

The target costing method allows identification of areas where efforts should be undertaken in order to reduce costs. However, it should be noted that these activities themselves also generate some costs that should be taken into account in order to avoid a situation in which the cost of their implementation is higher than the effect achieved. This situation is particularly undesirable if decisions made in the design stage generate additional costs in later phases of the product life cycle; for example, those related to operation. These can be higher costs of warranty repairs, maintenance or product recall costs. Therefore, the target costing technique should be supported by the product life cycle cost analysis.

The life cycle costing (LCC) analysis is a combination of the economic and technical aspects of the evaluated project over its projected duration. This method was initiated in the 1960s, and applied in many countries including the United States, where it has been widely used in the defense industry.

A general introduction to the concept of LCC estimation with a focus on costs related to product reliability has been presented in an international standard, while in Poland it was set forth originally in the (PN-EN 60300-3-3 n.d.): standard and next by the English standard (PN-EN 60300-3-3:2017-07 n.d.).

An important element in preparation of LCC models is an identification of costs that may have a significant impact on LCC (Cheung et al. 2007). When planning any investment or project, we must be aware of the costs of both purchase and ownership, and thus they must be taken into account in the decision-making process.

In the LCC method, the estimated life cycle cost is calculated as the sum of the acquisition costs, the cost of ownership and the operating costs according to the following formula (Nowak 2017):

$$
\mathrm{LCC}=\mathrm{K}_{\mathrm{A}}+\mathrm{K}_{\mathrm{O}}+\mathrm{K}_{\mathrm{Op}}
$$

where:

$\mathrm{K}_{\mathrm{N}}$-acquisition cost;

$\mathrm{K}_{\mathrm{O}}$-ownership cost;

$\mathrm{K}_{\mathrm{Op}}$-operating cost.

The acquisition costs relate to:

- $\quad$ Purchase costs (equipment purchase costs);

- Installation and assembly costs;

- Implementation support costs, crew training costs.

Ownership costs relate to:

- Costs of consumables;

- Labor cost;

- Maintenance and repair costs; 
- $\quad$ Energy costs.

However, the operating costs also include:

- Costs of using the product;

- Maintenance costs;

- Recall and decommissioning costs.

\subsection{Methods of Measuring the System's Economic Efficiency Evaluation}

A paper by Swiderski and Głogowski (2019) presents models based mainly on a subjective assessment of training participants and experts at various levels of training. All models presented in that paper are a modification of the classic Kirkpatrick model. Each of the models described in the abovementioned paper has both strong and weak points. It turns out that economic assessment of financial benefits arising from the acquired knowledge and skills of the employer and training participants is the biggest challenge in assessment.

However, these models do not take into account important economic issues. The purpose of this article is to show the economic viability of the system and the benefits of purchasing it. It continues discussion of the issues related to the effectiveness of training simulators, which is why the Kirkpatrick model was presented to give the reader a general view in this area.

Because the SPARTAN system trainer is a specific product, it is difficult to assess the economic analysis that was necessary to modify the existing methods for the calculation of economic indicators.

In addition to non-measurable values such as knowledge and skills, it is also necessary to select appropriate economic indicators and methods of their calculation. These indicators were assessed in another publication by Swiderski et al. (2020). The paper (Swiderski et al. 2020) presents the method of discounted cash flow NPV (net present value) in a simple version for the purchase of a new SPARTAN system. The NPV was calculated as the net present value of the project according to the following formula:

$$
\mathrm{NPV}=\sum_{\mathrm{t}=1}^{\mathrm{n}} \frac{\mathrm{CF}_{\mathrm{t}}}{(1+\mathrm{r})^{\mathrm{t}}}-\mathrm{I}_{0}
$$

where:

$\mathrm{NPV}$-net present value;

$\mathrm{CF}_{\mathrm{t}}$ - cash flows in period $\mathrm{t}$;

$\mathrm{r}$-discount rate;

I-initial expenditures;

$\mathrm{t}$-subsequent periods (usually years) of the project operation.

The following assumptions were made:

- The simulative cost of the system purchase in its basic version is approximately EUR 1,055,798.78;

- Period of operation (service life): 20 years and 30 years;

- The required rate of return for this investment is the so-called discount rate of $2 \%$;

- The average cost of buying 1 round of ammunition: EUR 0.7;

- The number of intensively trained soldiers to be assessed: $1 ; 10 ; 100 ; 1000$.

The obtained results are presented in Table 1.

The assumption that the service life of the SPARTAN system is 20 and 30 years is due to the fact that the service life of military equipment in the army is also similar. 
Table 1. Calculations of net present value (NPV) (Swiderski et al. 2020).

\begin{tabular}{ccc}
\hline $\begin{array}{c}\text { The Number of Soldiers to } \\
\text { Be Assessed }\end{array}$ & Service Life in Years & NPV in EUR \\
\hline \multirow{2}{*}{1} & 20 & $-1,044,347.00$ \\
& 30 & $-1,040,115.26$ \\
\hline \multirow{2}{*}{10} & 20 & $-810,521.28$ \\
& 30 & $-719,845.95$ \\
\hline \multirow{2}{*}{100} & 20 & $88,807.55$ \\
& 30 & $51,159.11$ \\
\hline \multirow{2}{*}{1000} & 20 & $10,390,210.56$ \\
& 30 & $14,621,726.11$ \\
\hline
\end{tabular}

The calculated NPV shows (Table 1) that purchase of the SPARTAN system makes business sense if the number of intensively trained soldiers is 100 and 1000 while the system's service life amounts to 20 and 30 years.

Another approach used in the project concerning the purchase of the SPARTAN system was the internal rate of return (IRR). This method was chosen because of its accuracy in terms of standard deviations and variances (Azar and Noueihed 2014). The NPV method is known to be the main argument in decision-making for capex budgeting (Bora 2015). It is effectively supplemented by the IRR method in the case of evaluation of independent conventional investment projects (Kulkov and Blaset 2020). Because a negative NPV was obtained for the number of soldiers amounting to 1 and 10, the project was not subjected to the IRR indicator approach. Therefore, when calculating the IRR, only the data that showed profit for 100 and 1000 intensively training soldiers were taken into account, for the service life of both 20 and 30 years. The IRR was calculated according to the formula below, and the calculated results are presented in Table 2:

$$
\operatorname{IRR}=\mathrm{i}_{1}+\frac{\mathrm{PV}\left(\mathrm{i}_{2}-\mathrm{i}_{1}\right)}{\mathrm{PV}+|\mathrm{NV}|}
$$

where:

IRR—internal rate of return;

PV-NPV calculated at $i_{1}$;

$\mathrm{NV}-\mathrm{NPV}$ calculated at $\mathrm{i}_{2}$;

$\mathrm{i}_{1}$ - discount rate at which NPV $>0$;

$\mathrm{i}_{2}$ - the discount rate at which NPV $<0$.

Table 2. Calculations of internal rate of return (IRR).

\begin{tabular}{ccc}
\hline $\begin{array}{c}\text { The Number of System Users (Trainees) to } \\
\text { Be Assessed }\end{array}$ & Service Life in Years & IRR Value in \% \\
\hline \multirow{2}{*}{100} & 20 & 1.00 \\
& 30 & 3.11 \\
\hline \multirow{2}{*}{1000} & 20 & 63.00 \\
& 30 & 63.04 \\
\hline
\end{tabular}

To sum up, the higher the IRR of a project, the more desirable it is to deliver it. A project with the highest IRR would probably be considered the best and selected to be the first for implementation.

Continuing further work related to the evaluation of the SPARTAN system's efficiency, one can analyze the LCC in respect of modernization of the abovementioned system. The LCC method, as mentioned above, refers to the estimated cost of product (in our case, the SPARTAN system) life cycle and it is calculated as the sum of the acquisition costs, ownership costs and operating costs. 
The following simulation data were adopted for the LCC analysis:

- Time covered by the analysis: 10 years (n);

- Discount rate: $2 \%$ (i).

The calculation results are shown in Table 3.

Table 3. Calculations of life cycle cost (LCC).

\begin{tabular}{|c|c|c|c|c|}
\hline No. & Costs (EUR) & & $\begin{array}{l}\text { Basic Version of the } \\
\text { SPARTAN System before } \\
\text { Modernization (EUR) }\end{array}$ & $\begin{array}{l}\text { SPARTAN System } \\
\text { after Modernization } \\
\text { (EUR) }\end{array}$ \\
\hline \multirow{5}{*}{1} & Acquisition & & & \\
\hline & Purchase & $\mathrm{K}_{\mathrm{P}}$ & $1,136,363.64$ & $1,363,636.36$ \\
\hline & Installation & $\mathrm{K}_{\mathrm{I}}$ & $45,454.55$ & $22,727.27$ \\
\hline & Training & $\mathrm{K}_{\mathrm{T}}$ & 2727.73 & 2272.73 \\
\hline & Total acquisition costs & $\mathrm{K}_{\mathrm{A}}=\mathrm{K}_{\mathrm{Z}}+\mathrm{K}_{\mathrm{I}}+\mathrm{K}_{\mathrm{T}}$ & $1,184,545.92$ & $1,388,636.36$ \\
\hline \multirow{5}{*}{2} & Ownership & & & \\
\hline & Consumables & $\mathrm{K}_{\mathrm{C}}$ & 1136.36 & 1136.36 \\
\hline & Maintenance and repair & $\mathrm{K}_{\mathrm{MR}}$ & 4545.45 & 2272.73 \\
\hline & Energy & $\mathrm{K}_{\mathrm{E}}$ & 2727.27 & 4545.45 \\
\hline & Total cost of ownership & $\mathrm{K}_{\mathrm{O}}=\mathrm{K}_{\mathrm{C}}+\mathrm{K}_{\mathrm{MR}}+\mathrm{K}_{\mathrm{E}}$ & 8409.09 & 7954.45 \\
\hline \multirow{5}{*}{3} & Operating costs & & & \\
\hline & Operation & $\mathrm{K}_{\mathrm{O}}$ & 272.73 & 272.73 \\
\hline & Maintenance & $\mathrm{K}_{\mathrm{M}}$ & $13,636.36$ & 6818.18 \\
\hline & $\begin{array}{l}\text { Removal from service } \\
\text { and decommissioning }\end{array}$ & $\mathrm{K}_{\mathrm{R}}$ & $14,772.73$ & $14,772.73$ \\
\hline & Total operating costs & $\mathrm{K}_{\mathrm{OP}}=\mathrm{K}_{\mathrm{O}}+\mathrm{K}_{\mathrm{M}}+\mathrm{K}_{\mathrm{R}}$ & $28,681.82$ & $21,863.64$ \\
\hline \multirow[t]{4}{*}{4} & LCC [EUR/10 years] & $\mathrm{LCC}=\mathrm{K}_{\mathrm{O}}+\mathrm{K}_{\mathrm{P}} /(1+\mathrm{i})^{\mathrm{n}}$ & $1,190,512.09$ & $1,394,229.64$ \\
\hline & $\begin{array}{l}\text { Share of acquisition costs } \\
\text { [\% in a period of } 10 \text { years] }\end{array}$ & $\mathrm{K}_{\mathrm{A}} / \mathrm{LCC}$ & $99 \%$ & $100 \%$ \\
\hline & $\begin{array}{l}\text { Share of ownership costs } \\
\text { [\% in a period of } 10 \text { years] }\end{array}$ & $\mathrm{K}_{\mathrm{O}} / \mathrm{LCC}$ & $1 \%$ & $0 \%$ \\
\hline & $\begin{array}{l}\text { Share of operating costs } \\
\text { [\% in a period of } 10 \text { years] }\end{array}$ & $\mathrm{K}_{\mathrm{OP}} / \mathrm{LCC}$ & $2 \%$ & $2 \%$ \\
\hline
\end{tabular}

Having taken into account costs of acquisition, ownership and operation, the result of the LCC analysis was obtained, which shows that, keeping in mind the whole the life cycle cost, it will be more profitable to purchase the modernized version of the SPARTAN system despite its higher acquisition costs. The time of owning-using the system, which is $0 \%$, is very important in this case. This is mainly due to the quality of the system, which will not require maintenance and repair, as is the case with the basic version.

Operating costs are also notable, and are definitely lower in the version after modernization compared to the system in its basic version. The consequence of lower operating costs is a lower cost of maintenance, which results from use of innovative technologies in the system, allowing for its remote servicing.

The modernization of the SPARTAN system referred to in this paper consists in an improvement of the realism of operation and preparing soldiers for combat operations, which is an important aspect of military personnel training. To obtain the effect of enhanced realism of operation, the system has been extended by addition of a treadmill for virtual reality, goggles and hand-mounted sensors that reflect real movements in the virtual world. For this reason, the purchase price of the upgraded SPARTAN system is higher than that of the basic version. 
In this case it was worth conducting the LCC analysis because it helped to prove that the upgraded version of the SPARTAN system actually generates savings because, despite the higher purchase cost, its operation is more cost-effective.

Following this example, it is also possible to conduct the cost simulation for another length of the service life, e.g., 15 or 20 years.

Due to the fact that the NPV and IRR ratios were calculated for the SPARTAN system before its modernization, it is also worth making calculations for comparative purposes, taking into account the higher purchase cost (after modernization), with the following assumptions:

- The simulation cost of purchasing the system in the basic version is approximately EUR 1,388,636.36;

- Service life: 20 years and 30 years;

- The required rate of return on this investment is the so-called discount rate of $2 \%$;

- $\quad$ Purchase cost of 1 round of ammunition on average is EUR 0.7;

- Number of soldiers in intensive training to be assessed: $1 ; 10 ; 100 ; 1000$.

After the calculations, the net present value (NPV-Tables 4 and 5) is as follows:

Table 4. Calculations of NPV.

\begin{tabular}{ccc}
\hline $\begin{array}{c}\text { The Number of System Users (Trainees) } \\
\text { to Be Assessed }\end{array}$ & Service Life in Years & NPV in EUR \\
\hline \multirow{2}{*}{1} & 20 & $-1,377,190.00$ \\
& 30 & $-1,372,958.84$ \\
\hline \multirow{2}{*}{10} & 20 & $-1,143,364.86$ \\
& 30 & $-1,052,689.53$ \\
\hline \multirow{2}{*}{100} & 20 & $-244,036.03$ \\
& 30 & $179,115.53$ \\
\hline \multirow{2}{*}{1000} & 20 & $10,057,366.98$ \\
& 30 & $14,288,882.53$ \\
\hline
\end{tabular}

Table 5. Summary of investment decisions depending on the NPV level (Azmat and Konzett 2014).

\begin{tabular}{cc}
\hline Net Present Value Is: & Then the Investment Should Be: \\
\hline Positive & $\begin{array}{c}\text { Accepted because the return on investment is greater than the } \\
\text { required rate of return }\end{array}$ \\
\hline Zero & $\begin{array}{c}\text { Accepted because the return on investment is greater than the } \\
\text { required rate of return }\end{array}$ \\
\hline Negative & Rejected because the return on investment is below the \\
required rate of return
\end{tabular}

\section{Conclusions}

- The purchase of the SPARTAN system is economically profitable with 100 intensively exercising soldiers over a service life of 30 years, as well as with 1000 soldiers over a service life of 20 and 30 years.

- The difference that is notable in the case of purchasing the system after modernization is that with 100 intensively exercising soldiers over a service life of 20 years, the purchase is unprofitable.

The second absolute discount method used for the SPARTAN purchase project is the internal rate of return (IRR).

The coefficient value for the same annual investment flows is also equal (Bednarz 2010) to:

$$
\text { PVA }=\text { Value of investments } / \text { annual cash flows }
$$




\section{In our case:}

- $\quad$ The simulation value of the SPARTAN system purchase is: EUR 1,388,636.36;

- Useful life: 20 years and 30 years;

- The application of the system will reduce the costs of ammunition consumption for 100 soldiers who exercise intensively by the amount of EUR 70,000.

After using the formula (5), we get:

$$
\text { PVA }=\text { EUR 1,388,636.36/EUR 70,000 = } 19.83
$$

For the period of 20 years and for 100 soldiers, the value of the coefficient 19.83 will correspond to an $\mathrm{r}$ rate within 1\% (see PVA tables-Bednarz 2010).

However, for 1000 soldiers who exercise intensively, the value of the coefficient will be 1.98 , which will correspond to an $\mathrm{r}$ rate above $50 \%$.

Using the IRR Formula (4) after the calculation, we get (see Table 6):

Table 6. Calculations of IRR.

\begin{tabular}{ccc}
\hline The Number of Soldiers & Period in Years & IRR Value in \% \\
\hline \multirow{2}{*}{100} & 20 & -2 \\
& 30 & 0.89 \\
\hline \multirow{2}{*}{1000} & 20 & 47 \\
& 30 & 47.46 \\
\hline
\end{tabular}

Generally speaking, the higher the IRR of a project, the more desirable it is to deliver it. The project with the highest IRR would probably be considered the best and taken first.

The IRR should be used in conjunction with other analyses to evaluate projects so that the user can determine its validity in the context of other benchmarks (Patrick and French 2016).

Author Contributions: Conceptualization, W.S. and W.R.; methodology, W.R.; software, W.S.; validation, W.S., and W.R.; formal analysis, W.R.; investigation, W.R.; resources, W.S.; data curation, W.S.; writing—original draft preparation, W.S.; writing—review and editing, W.S.; visualization, W.S. All authors have read and agreed to the published version of the manuscript.

Funding: This research received no external funding.

Institutional Review Board Statement: Not applicable.

Informed Consent Statement: Not applicable.

Conflicts of Interest: The authors declare no conflict of interest.

\section{References}

Azar, Samih, and Nazim Noueihed. 2014. A Probabilistic Internal Rate of Return. Theory and Illustration International Journal of Business and Management 9: 138.

Azmat, Muhammad, and Benjamin Konzett. 2014. Life Cycle Costing, Vienna, Austria. Available online: academia.edu/14750595 /Essay_on_Life_Cycle_Costing (accessed on 3 June 2021).

Bednarz, Krzysztof. 2010. Finance for Non-Financiers. Variable Value of Money over Time. Warsaw: Publishing House C.H. Beck. (In Polish)

Bora, Balaram. 2015. Comparison between NET present value and Internal Rate of Return. International Journal of Research in Finance and Marketing 5: 61-71.

Cheung, Wai M., Linda B. Newnes, Antony R. Mileham, Robert Marsh, and John D. Lanham. 2007. A study of life cycle costing in the perspectives of research and commercial applications in the 21st century. Paper presented at 12th Design for Manufacturing and the Life Cycle Conference, Pittsburgh, PA, USA, September 9-12.

Glogowski, Tomasz, Hlosta Pawel, Stepniak Slawomir, and Swiderski Waldemar. 2017. Optoelectronics applications in multimedia shooting training systems: SPARTAN. Electro-Optical and Infrared Systems: Technology and Applications XIV 10433. [CrossRef]

Kulkov, Nicolay Yu, and Anastasia Blaset. 2020. Rehabilitation of the Internal Rate of Return. Available online: https:/ / papers.ssrn. com/sol3/papers.cfm?abstract_id=3593173 (accessed on 9 June 2021).

Langdon, Davis. 2006. Literature Review of Life Cycle Costing (LCC) and Life Cycle Assessment (LCA). London: Davis Langdon Management Consulting. 
Liapis, Konstantionos J., and Dimitros D. Kantianis. 2015. Depreciation Methods and Life-Cycle Costing (LCC) Methodology. Procedia Economics and Finance 19: 314-24. [CrossRef]

Nowak, Edward. 2017. Advanced Management Acounting. Warszawa: PWE. (In Polish)

Patrick, Michael, and Nick French. 2016. The Internal Rate of Return (IRR): Projections, Benchmarks and Pitfalls. Oxford: Oxford Brookes University.

PN-EN 60300-3-3. n.d. Calculation of Life Cycle Cost According to Standard PN-EN 60300-3-3. Available online: www.sklep.pkn.pl (accessed on 3 June 2021). (In Polish).

PN-EN 60300-3-3:2017-07. n.d. Reliability Management. Application Guide-Estimating the Life Cycle Cost. Available online: www.sklep.pkn.pl (accessed on 3 June 2021).

Spickova, Marketa, and Renata Myskova. 2015. Costs Efficiency Evaluation using Life Cycle Costing as Strategic method. Procedia Economics and Finance 34: 337-43. [CrossRef]

Swiderski, Waldemar, and Tomasz Głogowski. 2019. Analysis of Possibilities for Evaluation of Training Simulators Efficiency on the Basis of "Snieznik" System. Problemy Techniki Uzbrojenia 151: 31-43. [CrossRef]

Swiderski, Waldemar, Głogowski Tomasz, Hlosta Pawel, and Stepniak Slawomir. 2018. IR Detection of Impact Places of Projectiles in the Training System "ŚNIEŻNIK". Problems of Mechatronics, Armament, Aviation, Safety Engineering 9: 99-110. [CrossRef]

Swiderski, Waldemar, Hlosta Pawel, Rolek Wieslawa, and Olpinski Wojciech. 2020. Preliminary analysis of shooting training systems: SPARTAN. In Electro-Optical and Infrared Systems: Technology and Applications XVII, 115370Q. Bellingham: International Society for Optics and Photonics. [CrossRef] 